NBER WORKING PAPER SERIES

\title{
CURRENCY WARS? UNCONVENTIONAL MONETARY POLICY DOES NOT STIMULATE EXPORTS
}

\author{
Andrew K. Rose \\ Working Paper 24817 \\ http://www.nber.org/papers/w24817 \\ NATIONAL BUREAU OF ECONOMIC RESEARCH \\ 1050 Massachusetts Avenue \\ Cambridge, MA 02138 \\ July 2018
}

* B.T. Rocca Jr. Professor, Haas School of Business at the University of California, Berkeley, NBER research associate, CEPR research fellow, and ABFER senior fellow. For hospitality during the course of this research, I thank the National University of Singapore. For discussions on related earlier work, I thank Reuven Glick. For comments, I thank Ross Levine, Mark Spiegel, Ken West and two anonymous referees. Current and earlier (longer) versions of this paper, the main STATA data sets used in the paper, and key output are all available at http:// faculty.haas.berkeley.edu/arose. The views expressed herein are those of the author and do not necessarily reflect the views of the National Bureau of Economic Research.

NBER working papers are circulated for discussion and comment purposes. They have not been peer-reviewed or been subject to the review by the NBER Board of Directors that accompanies official NBER publications.

(C) 2018 by Andrew K. Rose. All rights reserved. Short sections of text, not to exceed two paragraphs, may be quoted without explicit permission provided that full credit, including () notice, is given to the source. 
Currency Wars? Unconventional Monetary Policy Does Not Stimulate Exports

Andrew K. Rose

NBER Working Paper No. 24817

July 2018

JEL No. E58,F14

\begin{abstract}
$\underline{\text { ABSTRACT }}$
I investigate whether countries that use unconventional monetary policy (UMP) experience export booms. I use a popular gravity model of trade which requires neither the exogeneity of UMP, nor instrumental variables for UMP. In practice, countries that engage in UMP experience a drop in exports vis-á-vis countries that are not engaged in such policies, holding other things constant. Quantitative easing is associated with exports that are about 10\% lower to countries not engaged in UMP; this amount is significantly different from zero and similar to the effect of negative nominal interest rates. Thus, there is no evidence that countries have gained export markets through unconventional monetary policy; currency wars that have been launched have also been lost. UMP is also associated with a comparable drop in imports and exchange rates, suggesting that countries engage in UMP when they are experiencing adverse macroeconomic shocks concurrent with those that eviscerate international trade.
\end{abstract}

Andrew K. Rose

Haas School of Business Administration

University of California, Berkeley

Berkeley, CA 94720-1900

and CEPR

and also NBER

arose@ haas.berkeley.edu 
"We're in the midst of an international currency war, a general weakening of currency. This threatens us because it takes away our competitiveness..."

- Brazilian Finance Minister Guido Mantega, Mon Sep 27, 2010, reported by the Financial Times and Reuters

"A 'currency war' ... occurs when a country eases monetary policy specifically to depreciate its currency, with the ultimate objective of cheapening its exports and gaining unfair competitive advantage in international trade..."

- Ben Bernanke (2016, p2)

\section{Introduction}

In this short paper, I search for evidence of currency wars. More precisely, I look for signs that countries engaging in unconventional monetary policy (hereafter "UMP") subsequently experienced an actual boost to their exports, particularly to countries that did not use UMP. I do not find evidence of successful currency wars; in practice, countries that used quantitative easing and/or negative nominal interest rates actually suffered non-trivial reductions in their exports vis-à-vis countries that forewent UMP.

It is easy to motivate this investigation. In his 2015 Mundell-Fleming lecture, Ben Bernanke writes $(2015, \mathrm{p} 1)$ :

\footnotetext{
"I heard two related complaints at international meetings and through the media: First, that the United States was engaging in 'currency wars' - a phrase used most prominently by Brazilian finance minister Guido Mantega in 2010, following the Fed's introduction of a second round of quantitative easing - by choosing policies that would weaken the dollar and thereby unfairly increase US competitiveness at the expense of trading partners ... "1
}

Bernanke provides a forceful and persuasive defense of Fed actions; see also Bernanke (2016). However, he does so without providing much direct empirical evidence of the export effects, if any, of unconventional Fed policy. Doing so is part of the objective of this paper. 
I make three assumptions in my investigation. First, I identify currency wars with unconventional monetary policy; as Bernanke states, this issue first reared its head around the time of a round of quantitative easing. ${ }^{2}$ Second, I consider currency wars to be bilateral events between economies engaging in UMP (whom one might fancifully refer to as sources or "aggressors") and economies who have not used UMP ("targets" or "victims"). This corresponds to Mantega's statement in September 2010 “ 'The advanced countries are seeking to devalue their currencies' in order to increase exports, naming the United States, Europe and Japan ..." as quoted by Reuters. Third, I focus on the effects, if any, of unconventional monetary policy on exports, again consistent with the policy debate (though I also examine imports and exchange rates).

There is an extensive literature on broader aspects of unconventional monetary policy. Among many others, Haldane et al. (2016) and Greenlaw et al. (2018), discuss the evidence on quantitative easing, Arteta et al. (2016) provide the same for negative nominal interest rates, and all three provide extensive sets of references. To the best of my knowledge, no work focuses on the linkage between UMP and trade patterns; hence the focus of this analysis.

\section{Empirical Setup}

\section{Strategy}

I am interested in determining whether there have been successful currency wars; that is, whether a country engaged in UMP boosted its exports vis-à-vis countries that did not use UMP, ceteris paribus. One could imagine estimating the effect of UMP on exchange rates, and 
then the linkage between the exchange rate and trade patterns. Both are complicated problems, even ignoring the fact that UMP may have indirect effects on trade other than through the exchange rate. ${ }^{3}$ I sidestep such issues by directly examining the effect of UMP on trade. Since the objective of a competitive depreciation is to boost exports (and hence employment and output), this simplicity is appealing.

A naïve look at the data reveals little. Figure 1 contains time-series plots of quarterly nominal American exports and imports since 2005, along with dates when the three rounds of quantitative easing were initiated by the Federal Reserve. There is no obvious pattern to aggregate export behavior following this unconventional monetary policy. Both exports and imports continued to drop following QE1; QE2 seems to make little difference to trend growth in both exports and imports, while QE3 was followed by a flattening of trade. ${ }^{4}$

Such evidence is intrinsically superficial. Only one country's trade is considered; the multilateral nature of the data means that no distinction can be made between American exports to countries that were and were not engaging in their own quantitative easing; and no attempt is made to control for other factors driving trade. What is needed is a more comprehensive approach involving more countries, bilateral data, and a plausible econometric model parameterizing UMP; I now turn to that task.

\section{Methodology}

I pursue my investigation with "theory-consistent estimation" of the gravity equation of trade, closely following the suggestions in the recent survey by Head and Mayer (2014). This technique allows me to address concerns about "multilateral resistance" and other general 
equilibrium effects, while also allowing me to avoid potentially thorny identification problems. I rely on an extended version of the "LSDV" (Least Squares with time-varying country Dummy Variables) technique, which Head and Mayer show works well in many situations. In particular, I estimate:

$$
\ln \left(X_{i j t}\right)=\gamma U M P_{i j t}+\beta Z_{i j t}+\left\{\lambda_{i t}\right\}+\left\{\psi_{j t}\right\}+\left\{\phi_{i j}\right\}+\varepsilon_{i j t}
$$

where:

- $X_{i j t}$ denotes the nominal value of bilateral exports from $i$ to $j$ at time $t$,

- UMP is unity if $i$ uses unconventional monetary policy at time $t$ and $j$ does not, zero otherwise,

- $\beta$ is a vector of nuisance coefficients,

- $\mathrm{Z}$ is a vector of controls (dummy variables for currency unions and regional trade agreements),

- $\left\{\lambda_{i t}\right\}$ is a complete set of time-varying exporter dummy variables,

- $\left\{\psi_{j \mathrm{j}}\right\}$ is a complete set of time-varying importer dummy variables,

- $\left\{\phi_{\mathrm{ij}}\right\}$ is a complete set of time-invariant (dyadic) exporter-importer dummy variables, and

- $\varepsilon_{\mathrm{ijt}}$ represents the myriad other export determinants, assumed to be well behaved.

The coefficient of interest is $\gamma$ which links unconventional monetary policy to exports. Those who believe in successful currency wars hypothesize $\gamma>0$, so that countries engaging in quantitative easing, negative nominal interest rates and the like receive an export boost from countries not engaging in UMP. The econometric technique matches the economic question of 
interest, namely whether there have been successful currency wars. It does so in the context of an empirical model with a long track record of success, surveyed by Head and Mayer (2014).

$\underline{\text { Identification }}$

Equation (1) has one important regressor (UMP), two controls (Z) and a host of (over $50,000)$ fixed effects $\{\lambda, \psi, \phi\}$. The latter are the most striking feature of the setup, particularly the time-varying exporter and importer fixed effects. These hold constant all country-specific "monadic" phenomena, whether time-invariant (such as an exporter's land area or sea access), or time-varying (such as the state of an importer's business cycle or its level of financial distress during a particular period). ${ }^{5}$ Consistently, (1) can, even in principle, only be used to estimate the effect of phenomena that are both a) pair-specific and b) time-varying, like the effect of UMP by a country on its exports to a country that does not use UMP.

I estimate equation (1) with least squares on all observations with positive export flows; Head and Mayer (2014) provide an extensive discussion of related issues. An obvious question is whether unconventional monetary policy can be treated as exogenous. But since equation (1) includes a comprehensive set of time-varying exporter fixed effects, the answer is irrelevant, since the equation does not attempt to estimate the effect of, e.g., QE1 on American exports. From an econometric viewpoint, the reason is straightforward; the effect of any policy, shock, or other economic phenomena specific to a country during a particular period of time is swept away by the exporter-time and importer-time fixed effects. The implicit economic argument is that the model allows for two types of effects of unconventional monetary policy. One - which is implicitly included but which I do not explicitly estimate - is the common effect of UMP 
shocks (like QE1) on all American export flows similarly vis a vis any possible importer. It seems plausible that countries that decide to use UMP, for whatever reasons, do so for monadic reason (e.g., QE1 is implemented because of insufficient American aggregate demand, rocky banks, or whatever); thus, exogeneity issues are swept away. This makes sense if economies which engage in unconventional monetary policy do so in a monadic sense; when the United States implemented quantitative easing, it is interested in the effect on America. What $\gamma$ measures is any additional bilateral effect on an exporter engaging in UMP when the importer does not engage in UMP. To use a military metaphor, $\gamma$ measures the effect of a currency war by a belligerent on the defenders, not the effect of war on the belligerent. ${ }^{6}$ But it is important to remember that arguably the most important trade effects of unconventional monetary policy lie in the (monadic) fixed effects, which are simply controls in my reduced form analysis.

There remains the issue of specification error; perhaps some unmodeled phenomena, highly correlated with my empirical measure of UMP, remains unmodeled in the residual of (1), thereby inducing a biased estimate of $\gamma$. Indeed, the work of Eaton et al. (2016) points directly to shocks to the investment efficiency of durables. I try to check and corroborate my results by examining imports and exchange rates as well as exports, and by conducting an extensive set of robustness checks. Still, one can never discount such problems and I am accordingly cautious in interpreting the results of my reduced form empirical analysis.

\section{$\underline{\text { Data }}$}

For the main regressand (exports), I rely on the Direction of Trade data set assembled by the International Monetary Fund (IMF). This data set is wide; it covers bilateral trade between 
over 200 IMF country codes (with gaps). Not all the areas covered are countries in the conventional sense of the word; colonies (e.g., Falklands), territories (e.g., Guam), special administrative areas (e.g., Hong Kong), and so forth are all included; I use the term "country" simply for convenience. ${ }^{7}$ I collect quarterly data from 2000 (well before the global financial crisis) through the first half of 2016 (the most recent available data). I choose to work at the quarterly frequency as a compromise between the excessive noise in monthly data (monthly trade data are often lumpy or unavailable, especially for smaller countries), and the insufficiently granular annual frequency.

Bilateral trade on FOB exports and CIF imports is recorded in U.S. dollars. I create an average value of the nominal value of bilateral exports between two countries by averaging both measures available (i's exports to $\mathrm{j}$ and j's imports from i). As (Z) controls, I use two dummy variables; unity if $\mathrm{i}$ and $\mathrm{j}$ are in a currency union/regional trade agreement at time $\mathrm{t}$, and zero otherwise; the series are updated from Glick and Rose (2016), who provide more details. ${ }^{8}$

I also use a simple binary approach to measure unconventional monetary policy. I focus on two measures of unconventional monetary policy, using central bank websites to determine dates. I use these dates to construct binary variables, which are unity when the exporter engages in unconventional monetary policy and the importer does not, and are zero otherwise.

Perhaps the most important policy is quantitative easing (hereafter "QE"), balance sheet operations by central banks that entail the purchase of assets such as mortgage-backed securities or treasury bonds. For QE, I create a binary variable which is one for any quarter when the (exporter's) central bank is engaged in balance sheet operations (i.e., actively 
acquiring securities, while the importer's central bank is not), and zero otherwise. This discrete approach seems natural, and is widely used by the financial markets; it is also implicit in the work of, e.g., Greenlaw et al. (2018). Dates for QE are recorded in Table 1. I also consider two variants of QE dates: a) a comparable binary variable that uses either the execution or the announcement (rather than only the implementation) of QE; and b) a comparable binary variable if the central bank has a stock of outstanding assets on its balance sheets from QE, even if it is not actively engaging that quarter in further asset purchases. ${ }^{9}$ That is, my default measure of QE relies on the execution of asset purchase flows, while my variants rely on a) announcement dates for flow purchases, and b) outstanding stocks. ${ }^{10}$

The other UMP of greatest relevance is negative nominal interest rates (hereafter "NNIR"), which have been observed in Europe since 2011, and Japan more recently. Like QE, NNIR is a recent and persistent phenomenon. I consider nominal interest rates to be negative if short-term market rates are negative, following Hameed and Rose (2016). The NNIR binary variable is unity if the (exporter) economy experienced NNIR during the quarter (when the importer does not) and zero otherwise. I also consider a variant which is similar but uses official policy rather than market interest rates. ${ }^{11}$

Finally, mostly as a robustness check, I also consider state-contingent forward guidance, such as that used by the Federal Reserve beginning in December 2012, when an explicit (6.5\%) threshold for the unemployment rate was described as a necessary condition for interest rate "lift-off." 
Dates for both QE and NNIR are recorded in Table 1. Both QE and NNIR are rare in the data set, affecting less than $4.7 \%$ of the observations (forward guidance is even more obscure, at $0.3 \%$ of the sample). QE and NNIR policies are related, an issue to which I shall return below (the bilateral correlation coefficient is .43$).^{12}$

\section{Results}

\section{Benchmark Estimates for Exports}

Table 2 presents baseline estimates of equation (1). The table begins without any measures of UMP, in column 1 at the extreme left. The estimates indicate positive and statistically significant effects of the two (Z) controls on log exports; robust standard errors are recorded parenthetically and are clustered by exporter-importer dyad. The effect of currency unions is economically and statistically large, and comparable in magnitude to that estimated by Glick and Rose (2016); the regional trade agreement effect is much lower but still positive and statistically significant. While perhaps independently interesting, I ignore these nuisance coefficients hereafter. The equation fits well, with an $\mathrm{R}^{2}$ close to $90 \%$, and a root mean squared error of 1.37, approximately a third of the (3.98) standard deviation of log exports. This goodness of fit is unsurprising, since the model includes over 24,000 exporter-time and importer-time fixed effects as well as over 26,000 (dyadic) exporter-importer fixed effects. That is, the model seems to control adequately for a host of potential export determinants. 
Column 2 of Table 1 indicates that QE has a point estimate of -.09 when added by itself, so that QE (by the exporter but not the importer) is associated with an approximately $9 \%$ drop in exports, holding other things constant. This negative effect is significantly different from zero at any reasonable confidence level (the absolute t-statistic exceeds three). The QE estimate is comparable in both economic magnitude and statistical precision to the effect of NNIR, presented in column 3. Indeed, the hypothesis that the two have the same coefficient cannot be rejected (the F-test is .1).

Column 4 of Table 1 includes a measure for state-contingent interest rate forward guidance comparable to those for QE and NNIR; this has a small economic effect which is insignificantly different from zero at any confidence level $(t=-.2)$. Since the forward guidance effect shrinks further when included simultaneously with QE and NNIR in column 5, it is dropped hereafter; a possible reason is the relative obscurity of explicit state-contingent forward guidance, combined with its overlap with other types of UMP. The point estimate for the effect of either QE or NNIR, tabulated in column 7, is an economically substantive -.1, with a significant t-statistic exceeding three.

Table 1 provides no support for the hypothesis of currency wars; while a number of the $\gamma$ estimates are economically and statistically different from zero, they are negative, not positive. If countries deliberately try to boost their exports through unconventional monetary policy - a big "if" - it seems that they have been singularly unsuccessful in the attempt. 
$\underline{\text { Imports }}$

Judging from the anecdotes, currency wars seem to be more about boosting exports than suppressing imports. However, it is of obvious interest to investigate the effect of unconventional monetary policy on the behavior of imports. To check this, I simply replace the regressand in (1) with imports into i from $\mathrm{j}$ at time $\mathrm{t}$ and mutatis mutandis. ${ }^{13}$ Interestingly, the results in Table 3 are similar to those of Table 2 in both magnitude and sign.

Unconventional monetary policy, whether in the form of quantitative easing or negative nominal interest rates by an importer but not an exporter, is associated with about seven percent lower bilateral imports, ceteris paribus. ${ }^{14}$ The import equations fit approximately as well as the export equations, and both nuisance coefficients are similar in magnitude and size. It is inappropriate to make any causal claims, given the reduced form nature of the exercise. Nevertheless, when one country engages in unconventional monetary policy but another does not, trade flows in both directions seem to fall by comparable, statistically significant, amounts. I use this evidence further below to sketch out a potential story for my results.

$\underline{\text { Sensitivity Analysis }}$

Table 2 shows that if currency wars have been launched, they have not (yet) been won; unconventional monetary policy seems to be associated with a dampening rather than a stimulating effect on exports. Table 3 shows that the same is true of imports; that is, unconventional monetary policy is strongly correlated with reductions in trade in both directions. Table 4 provides evidence that this result is not a fragile result of the exact features 
of the econometric methodology. Each of the relevant (20) rows presents the results of a different perturbation of the baseline results. The column on the left records the coefficient estimate from (1) of $\gamma$ (and its robust standard error) when either quantitative easing or negative nominal interest rates are enacted by the exporter but not the importer. Next to it is an analogous column for imports, when unconventional monetary policy is enacted by the importer but not the exporter. For ease of comparison, the top row of Table 4 records benchmark results from the baseline, column 7 of Tables 2 and 3.

I begin with six variants of the key UMP regressor, measuring the presence of unconventional monetary policy in one of the two countries. First, I replace the default flowbased measure when $Q E$ is executed with a variant based on dates when QE was either announced or implemented. Second, I substitute the presence of outstanding stocks of assets purchased through QE, in place of the default QE measure. Third, I use official negative nominal interest rates in place of negative nominal market rates. None of these substitutions leads to much change in the size or statistical significance of the $\gamma$ coefficients. I then replace my UMP measures with (sequentially), the first lag of UMP, the fourth UMP lag (recall that this is a quarterly data set), and the first lead of UMP. Only one of these substitutions has much effect; import results are statistically insignificant (though similar in size) when one uses the fourth lag of UMP.

The remainder of Table 4 simply drops observations in a number of different ways. I first use only data after 2011. This leads the $\gamma$ coefficients to vanish in both economic and statistical significance. Since the tumult concerning currency wars occurred in the immediate 
aftermath of the global financial crisis of 2007-09, this may not be particularly surprising, but it is good to keep in mind that my results stem mostly from the pre-2012 period. By way of comparison, dropping the later part of the period makes little difference.

To see if the results are sensitive to the inclusion of any particular currency warrior ("UMP source"), I drop the exporter/importer observations of eight countries one by one; these countries either engaged in UMP or are large. Reassuringly, the results are quite robust. I then drop three large sets of importer/exporter countries (“UMP victim”) to see if the precise destinations for the exports/import sources matter; they do not. ${ }^{15}$ Finally, I drop all observations where the residual lies at least three standard errors away from its mean, again without changing the key results.

Appendix Tables A2 and A3 provide further robustness checks along the lines of Table 4. The column on the left of Table A2 records the coefficient estimate of $\gamma$ (and its robust standard error) when quantitative easing is the unconventional monetary policy in the exporter and not in the importer (as opposed to either quantitative easing or negative nominal interest rates, as in Table 4); analogous results for imports are in Table A3. In the center of Tables A2 and A3 are analogous columns for negative nominal interest rates. At the right, both QE and NNIR are included simultaneously in (1), and the p-value for the test of equal QE and NNIR effects is tabulated (high p-values are consistent with the null hypothesis of equality). For ease of comparison, the top row of Tables A2 and A3 records results from the baseline, columns 2 and 3 of Tables 2 and 3. In all cases, the results of Tables A2 and A3 are similar to and consistent with those of Table 4. Using the fourth lag delivers weak results and using data before 2011 is 
required for statistical significance. But even these exceptions refer to the statistical precision rather than the sign of the coefficients; in all other cases, the estimates of $\gamma$ remain negative, statistically significant, and similar in size to my baseline results.

To summarize: a large number of robustness checks shows that the results of Tables 2 and 3 are insensitive to the exact measure of UMP and sample of data. Either QE or NNIR is associated with an export decline, ceteris paribus, of around $10 \%$, while imports are associated with a somewhat smaller decline of around $7 \%$.

\section{$\underline{\text { Exchange Rates }}$}

The fact that unconventional monetary policy is associated with a non-trivial and robust decline in exports is grossly inconsistent with the positive estimate that a successful currency war might be expected to deliver. The fact that exports seem to fall - rather than remain unchanged, let alone rise - during periods of unconventional monetary policy is puzzling, and indeed this mystery is deepened by the simultaneous (if somewhat smaller) decline in imports. While a complete explanation remains beyond the scope of this non-structural exercise, I attempt to shed a little further light by examining nominal exchange rates.

Modeling the behavior of nominal bilateral exchange rates has proven to be exceedingly difficult for economists; Engel (2014) provides a recent survey. Rather than create a new model of exchange rate determination, I merely substitute the (natural logarithm of the) bilateral price of i's currency in terms of j's money as the regressand in (1), and re-estimate the benchmark 
results of Table 2, but for exchange rates rather than export flows. ${ }^{16}$ The results are presented in Appendix Table A4.

The motivating quotations by Mantega and Bernanke lead one to believe that UMP leads to exchange rate depreciation, and this intuition is born out in the results of Table A4. Unconventional monetary policy, either in the form of quantitative easing or negative nominal interest rates, is associated with a statistically and economically significant depreciation of around .6\%. Forward guidance seems not to play an appreciable role. That is, UMP is associated with the commonly expected exchange rate depreciation, even while it is also associated with a perversely negative effect on exports, as well as a similar decline in imports. It seems that any effect of UMP on the exchange rate was insufficient to stimulate exports sufficiently, at least given the other shocks occurring at the same time. But it is important to reiterate the caveat that my results should not be over-interpreted; gravity has proven to be a successful model of trade flows, but not of exchange rates.

\section{Monadic Fixed Effects}

The key coefficient of interest to me is $\gamma$, the response of log exports from a country with UMP to a country without UMP. This seems appropriate, since a hypothetical currency war links one or more aggressors (source countries engaged in UMP) to a set of potential victims or targets (countries not engaged in UMP). These are intrinsically bilateral relationships that vary over time. It is important to re-emphasize that $\gamma$ does not measure the response of log exports (or imports, or exchange rates) from a country with UMP vis-à-vis the rest of the world. Again, the effect of, e.g., the beginning of QE or NNIR on an exporter cannot be 
estimated in the context of (1); only relationships which are both a) time-varying and b)

bilateral are estimable. The presence of the $\left\{\lambda_{i t}\right\}$ terms (exporter-time fixed effects) means that anything which affects a given exporter at a point of time - including the multilateral effects of UMP on exports - is subsumed in the time-varying exporter fixed effects.

It may therefore be of interest to examine the latter $\left\{\lambda_{i t}\right\}$ terms, at least briefly. Figure 2 presents two event studies of estimates of $\left\{\lambda_{\text {it }}\right\}$. On the left, average quarterly values of $\left\{\lambda_{i t}\right\}$ during the two years, before, during, and after the onset of QE are portrayed, along with a $(5,95)$ confidence interval. The right-hand figure is analogous but portrays the time-varying exporter fixed effects around the time when market interest rates went negative. There is remarkably little movement in the fixed effects during the quarters around the start of these unconventional monetary policies. Exports seem not to change systematically around the years when a country begins UMP, whether in the form of QE or NNIR.

\section{Where Does This Lead?}

The evidence above indicates that when a country engages in unconventional monetary policy and its trading partner does not - either in the form of quantitative easing or negative nominal interest rates - the country experiences a decline in both its exports to and its imports from the partner along with a bilateral depreciation, ceteris paribus. None of this seems sensitive to the large number of robustness checks that I have employed.

The evidence I have presented is not structural, so drawing causal inferences about a potential mechanism is inappropriate. Nevertheless, some elements of a potential explanation that are consistent with the stylized facts presented here seem worth pursuing. First, it should 
be noted that these results are consistent with those in the literature. For instance, Eaton et al. (2016) study the collapse of international trade during the Great Recession of 2008-09 and attribute most to a shift away from tradables induced largely by a simultaneous (but not identical) decline in durable manufacturing investment efficiency. Interestingly, they attribute the recession and concomitant rise in unemployment to different shocks, particularly those to non-tradeable productivity and labor supply. These findings twin with the new evidence of this paper. They suggest that productivity and labor shocks induced UMP and the exchange rate depreciations, while trade declined along with investment efficiency. If so, one has the basis of a broadly consistent explanation, which awaits further, more structural exploration.

\section{Conclusion}

In this short paper, I ask if a currency war initiated by one country's use of unconventional monetary policy (UMP), whether deliberately or inadvertently, had the consequence of raising its exports to countries that did not use UMP. My answer is resoundingly negative; countries using quantitative easing and/or negative nominal interest rates simply did not experience export booms. This is consistent with negative and more general assessments of unconventional monetary policy made by, e.g., Greenlaw et al. (2018) and references therein. If anything, countries engaged in UMP saw their exports - as well as their imports and exchange rates - fall, holding other things constant.

Several possible extensions come to mind immediately. First, I measure both QE and NNIR as simple dummy variables. One could imagine constructing more continuous measures, 
which might be more revealing. Second, my definition of a currency war uses unconventional monetary policy; one could imagine using conventional monetary policy measures as well. Finally, currency wars entail an exchange rate depreciation to UMP and corresponding rise of exports. While I have found evidence of the former, there is none of the latter. What could account for the negative effect of UMP on exports to countries not engaging in UMP, especially given the expected exchange rate effect? Providing such evidence requires a structural investigation that lies beyond the scope of this study. 


\section{References}

Arteta, Carlos, M. Ayhan Kose, Marc Stocker and Temel Taskin (2016) “Negative Interest Rate Policies: Sources and Implications" CEPR DP 11, 433.

Bernanke, Ben (2015) "Federal Reserve Policy in an International Context" Mundell-Fleming lecture presented at the $16^{\text {th }}$ Jacques Polak IMF Annual Research Conference, https://www.imf.org/external/np/res/seminars/2015/arc/pdf/Bernanke.pdf .

Bernanke, Ben (2016) "What did you do in the currency war, Daddy?"

https://www.brookings.edu/blog/ben-bernanke/2016/01/05/what-did-you-do-in-the-currencywar-daddy/.

Eaton, Jonathan, Samuel Kortum, Brent Neiman and John Romalis (2016) "Trade and the Global Recession" American Economic Review 106(11), 3401-3438.

Engel, Charles M. (2014) "Exchange Rates and Interest Parity" in Handbook of International Economics vol. 4, edited by Gopinath, Helpman, and Rogoff (Elsevier, Amsterdam), 453-522.

Glick, Reuven and Andrew Rose (2016) "Currency Unions and Trade" European Economic Review 87, 78-91.

Greenlaw, David, James D. Hamilton, Ethan S. Harris and Kenneth D. West (2018) "A Skeptical View of the Impact of the Fed's Balance Sheet" https://research.chicagobooth.edu/igm/usmpf/usmpf-paper.

Haldane, Andrew, Matt Roberts-Sklar, Tomasz Wieladek, and Chris Young (2016) “QE: The Story so Far" CEPR DP 11,691.

Hameed, Allaudeen and Andrew Rose (2016) "Exchange Rate Behavior with Negative Interest Rates" http://faculty.haas.berkeley.edu/arose/NIRP.pdf .

Head, Keith and Thierry Mayer (2014) "Gravity Equations: Workhorse, Toolkit, and Cookbook" chapter 3 in Gopinath, G., E. Helpman, and K. Rogoff (eds), vol. 4 of the Handbook of International Economics (Elsevier, Amsterdam), 131-95. 
Table 1: Unconventional Monetary Policy, as of 2016Q2

\begin{tabular}{|l|c|c|}
\hline & Quantitative Easing & Negative Nominal Interest Rates \\
\hline USA, QE1 & 2008Q4-2010Q1 & \\
\hline USA, QE2 & $2010 Q 4-2011 Q 2$ & \\
\hline USA, QE3 & $2012 Q 3-2014 Q 4$ & \\
\hline UK, QE1 & $2009 Q 1-2010 Q 1$ & \\
\hline UK, QE2 & $2011 Q 4-2012 Q 2$ & \\
\hline UK, QE3 & $2012 Q 3-2012 Q 4$ & \\
\hline Switzerland & & $2011 Q 3-$ \\
\hline Denmark & & $2012 Q 3-$ \\
\hline Sweden & $2015 Q 1-$ & $2015 Q 1-$ \\
\hline Japan & $2001 Q 1-2006 Q 1$ & $2016 Q 1-$ \\
\hline Japan & $2010 Q 4-$ & \\
\hline EMU, CBBP & $2009 Q 3-2010 Q 2$ & \\
\hline EMU, SMP & $2010 Q 2-2012 Q 3$ & \\
\hline EMU, CBBP2 & $2011 Q 4-2012 Q 4$ & \\
\hline EMU, ABSPP, CBPP3 & $2014 Q 4-$ & \\
\hline EMU, PSPP & $2015 Q 1-$ & \\
\hline
\end{tabular}


Table 2: The Effect of Unconventional Monetary Policy on Exports

\begin{tabular}{|c|c|c|c|c|c|c|c|}
\hline & 1 & 2 & 3 & 4 & 5 & 6 & 7 \\
\hline $\begin{array}{l}\text { Quantitative Easing } \\
\text { by Exporter, not Importer (2.4\%) }\end{array}$ & & $\begin{array}{c}-.09 * * \\
(.02)\end{array}$ & & & $\begin{array}{c}-.07 * * \\
(.02)\end{array}$ & $\begin{array}{c}-.07 * * \\
(.02)\end{array}$ & \\
\hline $\begin{array}{l}\text { Negative Nominal Interest rate } \\
\text { in Exporter, not Importer }(2.5 \%)\end{array}$ & & & $\begin{array}{c}-.09 * * \\
(.03) \\
\end{array}$ & & $\begin{array}{l}-.06 \\
(.04)\end{array}$ & $\begin{array}{l}-.06 \\
(.03)\end{array}$ & \\
\hline $\begin{array}{l}\text { State-Contingent Forward Guidance } \\
\text { by Exporter, not Importer }(0.4 \%)\end{array}$ & & & & $\begin{array}{l}-.02 \\
(.10)\end{array}$ & $\begin{array}{c}.00 \\
(.10)\end{array}$ & & \\
\hline $\begin{array}{l}\text { Either Quantitative Easing or Negative Nominal } \\
\text { Interest rate by Exporter, not Importer }(4.1 \%)\end{array}$ & & & & & & & $\begin{array}{c}-.10^{* *} \\
(.02)\end{array}$ \\
\hline $\begin{array}{l}\text { Currency } \\
\text { Union }\end{array}$ & $\begin{array}{l}.35^{* *} \\
(.05)\end{array}$ & $\begin{array}{l}.31^{* *} \\
(.05)\end{array}$ & $\begin{array}{l}.32 * * \\
(.05)\end{array}$ & $\begin{array}{l}.35^{* *} \\
(.05)\end{array}$ & $\begin{array}{l}.29 * * \\
(.05)\end{array}$ & $\begin{array}{l}.29 * * \\
(.05)\end{array}$ & $\begin{array}{l}.30 * * \\
(.05)\end{array}$ \\
\hline $\begin{array}{l}\text { Regional Trade } \\
\text { Agreement }\end{array}$ & $\begin{array}{l}.04 * \\
(.02)\end{array}$ & $\begin{array}{l}.04^{*} \\
(.02)\end{array}$ & $\begin{array}{l}.04^{*} \\
(.02)\end{array}$ & $\begin{array}{l}.04^{*} \\
(.02) \\
\end{array}$ & $\begin{array}{l}.04^{*} \\
(.01)\end{array}$ & $\begin{array}{l}.04^{*} \\
(.02)\end{array}$ & $\begin{array}{l}.04^{*} \\
(.02)\end{array}$ \\
\hline Exporter-Quarter Fixed Effects $(11,773)$ & Yes & Yes & Yes & Yes & Yes & Yes & Yes \\
\hline Importer-Quarter Fixed Effects $(12,997)$ & Yes & Yes & Yes & Yes & Yes & Yes & Yes \\
\hline Exporter-Importer Fixed Effects $(26,096)$ & Yes & Yes & Yes & Yes & Yes & Yes & Yes \\
\hline $\mathbf{R}^{2}$ & .89 & .89 & .89 & .89 & .89 & .89 & .89 \\
\hline RMSE & 1.37 & 1.37 & 1.37 & 1.37 & 1.37 & 1.37 & 1.37 \\
\hline
\end{tabular}

Coefficients, with robust standard errors (clustered by country-pair dyad) recorded in parentheses. Coefficients significantly different from zero at the .05 (.01) level marked by one (two) asterisk(s). Each column stems from a separate regression. Least squares estimation; regressand is log bilateral exports in US\$. Fixed effects included for all sets of: a) exporter*quarter, b) importer*quarter, and c) exporter*importer. Quarterly data 2000Q1-2016Q2 for over 200 countries and territories; 1,313,527 observations. 
Table 3: The Effect of Unconventional Monetary Policy on Imports

\begin{tabular}{|c|c|c|c|c|c|c|c|}
\hline & 1 & 2 & 3 & 4 & 5 & 6 & 7 \\
\hline $\begin{array}{l}\text { Quantitative Easing } \\
\text { by Importer, not Exporter (2.4\%) }\end{array}$ & & $\begin{array}{c}-.08 * * \\
(.02)\end{array}$ & & & $\begin{array}{c}-.07 * * \\
(.02)\end{array}$ & $\begin{array}{c}-.07 * * \\
(.04)\end{array}$ & \\
\hline $\begin{array}{l}\text { Negative Nominal Interest rate } \\
\text { in Importer, not Exporter }(2.5 \%)\end{array}$ & & & $\begin{array}{c}-.08 * * \\
(.03)\end{array}$ & & $\begin{array}{l}-.06 \\
(.03)\end{array}$ & $\begin{array}{l}-.06 \\
(.03)\end{array}$ & \\
\hline $\begin{array}{l}\text { State-Contingent Forward Guidance } \\
\text { by Importer, not Exporter (0.4\%) }\end{array}$ & & & & $\begin{array}{l}-.03 \\
(.11)\end{array}$ & $\begin{array}{l}-.01 \\
(.11)\end{array}$ & & \\
\hline $\begin{array}{l}\text { Either Quantitative Easing or Negative Nominal } \\
\text { Interest rate by Importer, not Exporter }(4.1 \%)\end{array}$ & & & & & & & $\begin{array}{c}-.07^{* *} \\
(.03)\end{array}$ \\
\hline $\begin{array}{l}\text { Currency } \\
\text { Union }\end{array}$ & $\begin{array}{l}.33 * * \\
(.05)\end{array}$ & $\begin{array}{l}.29 * * \\
(.05)\end{array}$ & $\begin{array}{l}.31^{* *} \\
(.05)\end{array}$ & $\begin{array}{l}.33^{* *} \\
(.05)\end{array}$ & $\begin{array}{l}.28 * * \\
(.05)\end{array}$ & $\begin{array}{l}.28 * * \\
(.05)\end{array}$ & $\begin{array}{l}.29 * * \\
(.05)\end{array}$ \\
\hline $\begin{array}{l}\text { Regional Trade } \\
\text { Agreement }\end{array}$ & $\begin{array}{l}.05 * * \\
(.02)\end{array}$ & $\begin{array}{l}.06 * * \\
(.02)\end{array}$ & $\begin{array}{l}.06 * * \\
(.02)\end{array}$ & $\begin{array}{l}.05 * * \\
(.02)\end{array}$ & $\begin{array}{l}.06 * * \\
(.02) \\
\end{array}$ & $\begin{array}{l}.06 * * \\
(.02)\end{array}$ & $\begin{array}{l}.06 * * \\
(.02)\end{array}$ \\
\hline Exporter-Quarter Fixed Effects $(11,776)$ & Yes & Yes & Yes & Yes & Yes & Yes & Yes \\
\hline Importer-Quarter Fixed Effects $(12,997)$ & Yes & Yes & Yes & Yes & Yes & Yes & Yes \\
\hline Exporter-Importer Fixed Effects $(27,172)$ & Yes & Yes & Yes & Yes & Yes & Yes & Yes \\
\hline $\mathbf{R}^{2}$ & .89 & .89 & .89 & .89 & .89 & .89 & .89 \\
\hline RMSE & 1.39 & 1.39 & 1.39 & 1.39 & 1.39 & 1.39 & 1.39 \\
\hline
\end{tabular}

Coefficients, with robust standard errors (clustered by country-pair dyad) recorded in parentheses. Coefficients significantly different from zero at the .05 (.01) level marked by one (two) asterisk(s). Each column stems from a separate regression. Least squares estimation; regressand is log bilateral imports in US\$. Fixed effects included for all sets of: a) exporter*quarter, b) importer*quarter, and c) exporter*importer. Quarterly data 2000Q1-2016Q2 for over 200 countries and territories; 1,325,058 observations. 
Table 4: The Effect of Unconventional Monetary Policy on Trade, Sensitivity Analysis

\begin{tabular}{|c|c|c|}
\hline & \multicolumn{2}{|c|}{ Either Quantitative Easing or Negative Nominal Interest Rates in } \\
\hline & Exporter, not Importer & Importer, not Exporter \\
\hline Default & $\begin{array}{c}-.10^{* *} \\
(.02)\end{array}$ & $\begin{array}{l}-.07^{*} \\
(.03)\end{array}$ \\
\hline Substitute Announced QE & $\begin{array}{c}-.09 * * \\
(.02)\end{array}$ & $\begin{array}{c}-.07 * * \\
(.03)\end{array}$ \\
\hline Substitute Stock QE & $\begin{array}{c}-.13^{* *} \\
(.03)\end{array}$ & $\begin{array}{c}-.10 * * \\
(.03)\end{array}$ \\
\hline $\begin{array}{l}\text { Substitute Negative Official Policy } \\
\text { Interest Rate }\end{array}$ & $\begin{array}{c}-.10^{* *} \\
(.02)\end{array}$ & $\begin{array}{c}-.08^{* *} \\
(.02)\end{array}$ \\
\hline First lag of UMP & $\begin{array}{c}-.10^{* *} \\
(.02)\end{array}$ & $\begin{array}{c}-.07 * * \\
(.02)\end{array}$ \\
\hline Fourth lag of UMP & $\begin{array}{l}-.07^{*} \\
(.02)\end{array}$ & $\begin{array}{l}-.05 \\
(.02)\end{array}$ \\
\hline First lead of UMP & $\begin{array}{c}-.10^{* *} \\
(.02)\end{array}$ & $\begin{array}{c}-.08 * * \\
(.03) \\
\end{array}$ \\
\hline After 2011 & $\begin{array}{l}-.02 \\
(.02)\end{array}$ & $\begin{array}{l}-.01 \\
(.02)\end{array}$ \\
\hline Before 2016 & $\begin{array}{c}-.08^{* *} \\
(.02)\end{array}$ & $\begin{array}{c}-.06^{* *} \\
(.02)\end{array}$ \\
\hline $\begin{array}{l}\text { Drop US } \\
\text { as UMP source }\end{array}$ & $\begin{array}{c}-.10^{* *} \\
(.03)\end{array}$ & $\begin{array}{c}-.07^{* *} \\
(.03)\end{array}$ \\
\hline $\begin{array}{l}\text { Drop UK } \\
\text { as UMP source }\end{array}$ & $\begin{array}{c}-.10^{* *} \\
(.03)\end{array}$ & $\begin{array}{c}-.08^{* *} \\
(.03)\end{array}$ \\
\hline $\begin{array}{l}\text { Drop Japan } \\
\text { as UMP source }\end{array}$ & $\begin{array}{c}-.10 * * \\
(.03)\end{array}$ & $\begin{array}{c}-.07 * * \\
(.03)\end{array}$ \\
\hline $\begin{array}{l}\text { Drop Denmark } \\
\text { as UMP source }\end{array}$ & $\begin{array}{c}-.10^{* *} \\
(.03)\end{array}$ & $\begin{array}{l}-.07^{*} \\
(.03) \\
\end{array}$ \\
\hline $\begin{array}{l}\text { Drop Sweden } \\
\text { as UMP source }\end{array}$ & $\begin{array}{c}-.09 * * \\
(.02)\end{array}$ & $\begin{array}{c}-.07^{* *} \\
(.03)\end{array}$ \\
\hline $\begin{array}{l}\text { Drop Switzerland } \\
\text { as UMP source }\end{array}$ & $\begin{array}{c}-.09 * * \\
(.03)\end{array}$ & $\begin{array}{c}-.09 * * \\
(.02)\end{array}$ \\
\hline $\begin{array}{l}\text { Drop Germany } \\
\text { as UMP source }\end{array}$ & $\begin{array}{c}-.09 * * \\
(.03)\end{array}$ & $\begin{array}{l}-.07^{*} \\
(.03)\end{array}$ \\
\hline $\begin{array}{l}\text { Drop China, HK } \\
\text { as UMP source }\end{array}$ & $\begin{array}{c}-.09 * * \\
(.02)\end{array}$ & $\begin{array}{c}-.07 * * \\
(.03)\end{array}$ \\
\hline $\begin{array}{l}\text { Drop Asians DCs } \\
\text { as UMP "target" }\end{array}$ & $\begin{array}{c}.10^{* *} \\
(.03)\end{array}$ & $\begin{array}{c}-.08^{* *} \\
(.03)\end{array}$ \\
\hline $\begin{array}{l}\text { Drop Africans } \\
\text { as UMP "target" }\end{array}$ & $\begin{array}{c}-.09 * * \\
(.02) \\
\end{array}$ & $\begin{array}{c}-.08^{* *} \\
(.02) \\
\end{array}$ \\
\hline $\begin{array}{l}\text { Drop Latin/Caribbean } \\
\text { as UMP "target" }\end{array}$ & $\begin{array}{c}-.10^{* *} \\
(.02)\end{array}$ & $\begin{array}{l}-.04 \\
(.03)\end{array}$ \\
\hline Drop $3 \sigma$ outliers & $\begin{array}{c}-.08^{* *} \\
(.02)\end{array}$ & $\begin{array}{c}-.06^{* *} \\
(.02)\end{array}$ \\
\hline
\end{tabular}

Coefficients, with robust standard errors (clustered by country-pair dyad) recorded in parentheses. Coefficients significantly different from zero at the .05 (.01) level marked by one (two) asterisk(s). Each cell stems from a separate regression. Least squares estimation; regressand is log bilateral exports/imports in US\$. Binary regressors included but not recorded for exporter + importer in: a) currency union; and b) regional trade agreement. Fixed effects included for all sets of: a) exporter*quarter, b) importer*quarter, and c) exporter*importer. Quarterly data 2000Q1-2016Q2 for over 200 countries and territories; default export regression has 1,313,527 observations, while default import regression has 1,325,058 observations. 
Figure 1

American Trade around Quantitative Easing Rounds International Trade in Goods and Services, USD bn
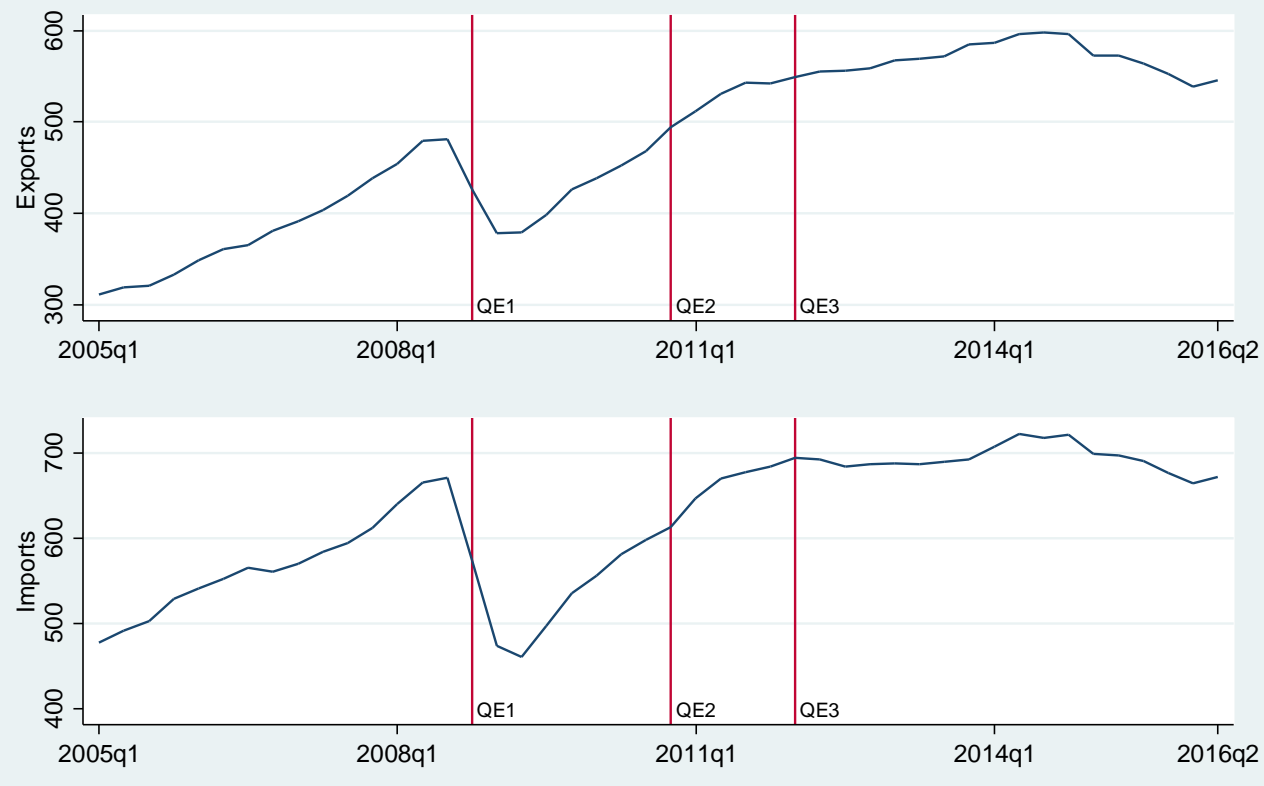

Figure 2

Fixed Effects around Start of Unconventional Monetary Policy Exporter $x$ Date FE from LSDV gravity model with dyadic FE
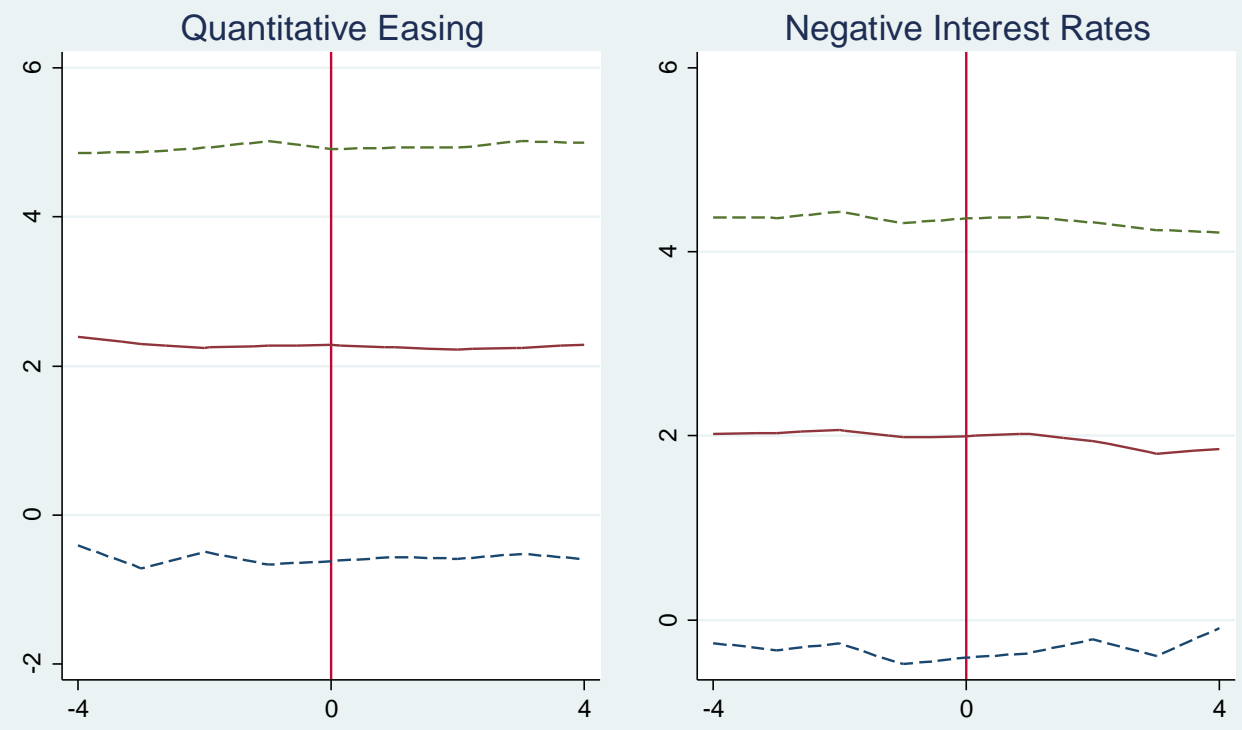

Means with $(5,95)$ confidence interval. 2000Q1-2016Q2 data, >200 countries and territories. 


\section{Appendix Table A1: List of Countries}

\begin{tabular}{|c|c|c|c|}
\hline Afghanistan & Dominica & Lebanon & Senegal \\
\hline Albania & Dominican Republic & Lesotho & Serbia \\
\hline Algeria & Ecuador & Liberia & Serbia \& Montenegro \\
\hline American Samoa & Egypt & Libya & Seychelles \\
\hline Angola & El Salvador & Lithuania & Sierra Leone \\
\hline Antigua \& Barbuda & Equatorial Guinea & Luxembourg & Singapore \\
\hline Argentina & Eritrea & Macedonia & Slovak Republic \\
\hline Armenia & Estonia & Madagascar & Slovenia \\
\hline Aruba & Ethiopia & Malawi & Solomon Islands \\
\hline Australia & Falkland Islands & Malaysia & Somalia \\
\hline Austria & Faroe Islands & Maldives & South Africa \\
\hline Azerbaijan & Fiji & Mali & South Sudan \\
\hline Bahamas & Finland & Malta & Spain \\
\hline Bahrain & France & Mauritania & Sri Lanka \\
\hline Bangladesh & Gabon & Mauritius & St. Kitts \& Nevis \\
\hline Barbados & Gambia & Mexico & St. Lucia \\
\hline Belarus & Georgia & Moldova & St. Vincent \& \\
\hline Belgium & Germany & Mongolia & Grenadines \\
\hline Belize & Ghana & Montenegro & Sudan \\
\hline Benin & Gibraltar & Morocco & Suriname \\
\hline Bermuda & Greece & Mozambique & Swaziland \\
\hline Bhutan & Greenland & Myanmar & Sweden \\
\hline Bolivia & Grenada & Namibia & Switzerland \\
\hline Bosnia \& Herzegovina & Guam & Nauru & Syria \\
\hline Botswana & Guatemala & Nepal & Taiwan \\
\hline Brazil & Guinea & Netherlands & Tajikistan \\
\hline Brunei Darussalam & Guinea-Bissau & Netherlands Antilles & Tanzania \\
\hline Bulgaria & Guyana & New Caledonia & Thailand \\
\hline Burkina Faso & Haiti & New Zealand & Timor-Leste \\
\hline Burundi & Honduras & Nicaragua & Togo \\
\hline Cambodia & Hungary & Niger & Tonga \\
\hline Cameroon & Iceland & Nigeria & Trinidad \& Tobago \\
\hline Canada & India & Norway & Tunisia \\
\hline Cape Verde & Indonesia & Oman & Turkey \\
\hline Central African Republic & Iran & Pakistan & Turkmenistan \\
\hline Chad & Iraq & Palau & Tuvalu \\
\hline Chile & Ireland & Panama & Uganda \\
\hline China, Hong Kong & Israel & Papua New Guinea & Ukraine \\
\hline China, Macao & Italy & Paraguay & United Arab Emirates \\
\hline China, Mainland & Jamaica & Peru & United Kingdom \\
\hline Colombia & Japan & Philippines & United States \\
\hline Comoros & Jordan & Poland & Uruguay \\
\hline Congo, DR & Kazakhstan & Portugal & Uzbekistan \\
\hline Congo, Rep & Kenya & Qatar & Vanuatu \\
\hline Costa Rica & Kiribati & Romania & Venezuela \\
\hline Cote d'Ivoire & Korea, North & Russian Federation & Vietnam \\
\hline Croatia & Korea, South & Rwanda & West Bank \& Gaza \\
\hline Cuba & Kosovo & Saint Helena & Yemen \\
\hline Cyprus & Kuwait & Saint Pierre \& Miquelon & Zambia \\
\hline Czech Republic & Kyrgyz Republic & Samoa & Zimbabwe \\
\hline Denmark & Laos & Sao Tome \& Principe & \\
\hline Djibouti & Latvia & Saudi Arabia & \\
\hline
\end{tabular}


Appendix Table A2: Unconventional Monetary Policy and Exports, Sensitivity Analysis

\begin{tabular}{|c|c|c|c|}
\hline & $\begin{array}{l}\text { Quantitative Easing by } \\
\text { Exporter, not Importer }\end{array}$ & $\begin{array}{l}\text { Neg. Nom. Int. Rate } \\
\text { in Exporter, not } \\
\text { Importer }\end{array}$ & $\begin{array}{c}\text { Test for Equality } \\
\text { (p-value) }\end{array}$ \\
\hline Default & $\begin{array}{c}-.09 * * \\
(.02) \\
\end{array}$ & $\begin{array}{c}-.09 * * \\
(.03)\end{array}$ & .73 \\
\hline Substitute Announced QE & $\begin{array}{c}-.08 * * \\
(.02) \\
\end{array}$ & & .96 \\
\hline Substitute Stock QE & $\begin{array}{c}.13^{* *} \\
(.03)\end{array}$ & & .06 \\
\hline $\begin{array}{l}\text { Substitute Negative } \\
\text { Official Policy Interest } \\
\text { Rate }\end{array}$ & & $\begin{array}{c}-.09 * * \\
(.03)\end{array}$ & .99 \\
\hline First lag of UMP & $\begin{array}{c}-.09 * * \\
(.02) \\
\end{array}$ & $\begin{array}{l}-.07^{*} \\
(.03) \\
\end{array}$ & .36 \\
\hline Fourth lag of UMP & $\begin{array}{l}-.06^{*} \\
(.02)\end{array}$ & $\begin{array}{l}-.06 \\
(.03)\end{array}$ & .98 \\
\hline First lead of UMP & $\begin{array}{c}-.08^{* *} \\
(.02) \\
\end{array}$ & $\begin{array}{c}-.09 * * \\
(.03) \\
\end{array}$ & .94 \\
\hline After 2011 & $\begin{array}{l}-.01 \\
(.02) \\
\end{array}$ & $\begin{array}{c}-.04 \\
(.03) \\
\end{array}$ & .52 \\
\hline Before 2016 & $\begin{array}{c}-.07 * * \\
(.02) \\
\end{array}$ & $\begin{array}{l}-.06 \\
(.03) \\
\end{array}$ & .47 \\
\hline $\begin{array}{l}\text { Drop US } \\
\text { as UMP source }\end{array}$ & $\begin{array}{c}-.09 * * \\
(.02) \\
\end{array}$ & $\begin{array}{c}-.09 * * \\
(.03) \\
\end{array}$ & .68 \\
\hline $\begin{array}{l}\text { Drop UK } \\
\text { as UMP source }\end{array}$ & $\begin{array}{c}-.09 * * \\
(.02)\end{array}$ & $\begin{array}{c}-.09 * * \\
(.03)\end{array}$ & .85 \\
\hline $\begin{array}{l}\text { Drop Japan } \\
\text { as UMP source }\end{array}$ & $\begin{array}{c}-.09 * * \\
(.02)\end{array}$ & $\begin{array}{l}-.08^{*} \\
(.03)\end{array}$ & .55 \\
\hline $\begin{array}{l}\text { Drop Denmark } \\
\text { as UMP source }\end{array}$ & $\begin{array}{c}-.08^{* *} \\
(.02)\end{array}$ & $\begin{array}{l}-.08^{*} \\
(.03)\end{array}$ & .63 \\
\hline $\begin{array}{l}\text { Drop Sweden } \\
\text { as UMP source }\end{array}$ & $\begin{array}{c}-.08^{* *} \\
(.02) \\
\end{array}$ & $\begin{array}{l}-.08^{*} \\
(.03)\end{array}$ & .66 \\
\hline $\begin{array}{l}\text { Drop Switzerland } \\
\text { as UMP source }\end{array}$ & $\begin{array}{c}-.08^{* *} \\
(.02) \\
\end{array}$ & $\begin{array}{c}-.11^{* *} \\
(.03) \\
\end{array}$ & .46 \\
\hline $\begin{array}{l}\text { Drop Germany } \\
\text { as UMP source }\end{array}$ & $\begin{array}{c}-.08 * * \\
(.02) \\
\end{array}$ & $\begin{array}{l}-.08 * \\
(.03)\end{array}$ & .82 \\
\hline $\begin{array}{l}\text { Drop China, HK } \\
\text { as UMP source }\end{array}$ & $\begin{array}{c}-.08^{* *} \\
(.02) \\
\end{array}$ & $\begin{array}{l}-.08^{*} \\
(.03) \\
\end{array}$ & .66 \\
\hline $\begin{array}{l}\text { Drop Asians DCs } \\
\text { as UMP "target" }\end{array}$ & $\begin{array}{c}-.09 * * \\
(.03)\end{array}$ & $\begin{array}{c}-.11 * * \\
(.04)\end{array}$ & .78 \\
\hline $\begin{array}{l}\text { Drop Africans } \\
\text { as UMP "target" }\end{array}$ & $\begin{array}{c}-.09 * * \\
(.02) \\
\end{array}$ & $\begin{array}{l}-.07^{*} \\
(.03)\end{array}$ & .45 \\
\hline $\begin{array}{l}\text { Drop Latin/Caribbean } \\
\text { as UMP "target" }\end{array}$ & $\begin{array}{l}-.05^{*} \\
(.02) \\
\end{array}$ & $\begin{array}{l}-.07^{*} \\
(.03)\end{array}$ & .85 \\
\hline Drop $3 \sigma$ outliers & $\begin{array}{c}.07^{* *} \\
(.02)\end{array}$ & $\begin{array}{l}-.06^{*} \\
(.03)\end{array}$ & .69 \\
\hline
\end{tabular}

Coefficients, with robust standard errors (clustered by country-pair dyad) recorded in parentheses. Coefficients significantly different from zero at the .05 (.01) level marked by one (two) asterisk(s). Each cell stems from a separate regression. Least squares estimation; regressand is log bilateral exports in US\$. Binary regressors included but not recorded for exporter + importer in: a) currency union; and b) regional trade agreement. Fixed effects included for all sets of: a) exporter*quarter, b) importer*quarter, and c) exporter*importer. Quarterly data 2000Q1-2016Q2 for over 200 countries and territories; default regression has 1,313,527 observations. 
Appendix Table A3: Unconventional Monetary Policy and Imports, Sensitivity Analysis

\begin{tabular}{|c|c|c|c|}
\hline & $\begin{array}{l}\text { Quantitative Easing by } \\
\text { Importer, not Exporter }\end{array}$ & $\begin{array}{l}\text { Neg. Nom. Int. Rate } \\
\text { in Importer, not } \\
\text { Exporter }\end{array}$ & $\begin{array}{c}\text { Test for Equality } \\
\text { (p-value) }\end{array}$ \\
\hline Default & $\begin{array}{c}-.08^{* *} \\
(.02) \\
\end{array}$ & $\begin{array}{c}-.08 * * \\
(.03)\end{array}$ & .83 \\
\hline Substitute Announced QE & $\begin{array}{c}-.08 * * \\
(.02) \\
\end{array}$ & & .98 \\
\hline Substitute Stock QE & $\begin{array}{c}.13^{* *} \\
(.03)\end{array}$ & & .07 \\
\hline $\begin{array}{l}\text { Substitute Negative } \\
\text { Official Policy Interest } \\
\text { Rate }\end{array}$ & & $\begin{array}{c}-.09 * * \\
(.03)\end{array}$ & .90 \\
\hline First lag of UMP & $\begin{array}{c}-.09 * * \\
(.02) \\
\end{array}$ & $\begin{array}{l}-.07^{*} \\
(.03) \\
\end{array}$ & .41 \\
\hline Fourth lag of UMP & $\begin{array}{l}-.06^{*} \\
(.02)\end{array}$ & $\begin{array}{l}-.06 \\
(.03)\end{array}$ & .96 \\
\hline First lead of UMP & $\begin{array}{c}-.08^{* *} \\
(.02) \\
\end{array}$ & $\begin{array}{c}-.09 * * \\
(.03) \\
\end{array}$ & .89 \\
\hline After 2011 & $\begin{array}{l}-.01 \\
(.02) \\
\end{array}$ & $\begin{array}{c}-.04 \\
(.03) \\
\end{array}$ & .25 \\
\hline Before 2016 & $\begin{array}{c}-.07 * * \\
(.02) \\
\end{array}$ & $\begin{array}{l}-.06 \\
(.03) \\
\end{array}$ & .58 \\
\hline $\begin{array}{l}\text { Drop US } \\
\text { as UMP source }\end{array}$ & $\begin{array}{c}-.09 * * \\
(.02) \\
\end{array}$ & $\begin{array}{c}-.09 * * \\
(.03) \\
\end{array}$ & .84 \\
\hline $\begin{array}{l}\text { Drop UK } \\
\text { as UMP source }\end{array}$ & $\begin{array}{c}-.09 * * \\
(.02)\end{array}$ & $\begin{array}{c}-.09 * * \\
(.03)\end{array}$ & .79 \\
\hline $\begin{array}{l}\text { Drop Japan } \\
\text { as UMP source }\end{array}$ & $\begin{array}{c}-.09 * * \\
(.02)\end{array}$ & $\begin{array}{c}-.08^{* *} \\
(.03)\end{array}$ & .75 \\
\hline $\begin{array}{l}\text { Drop Denmark } \\
\text { as UMP source }\end{array}$ & $\begin{array}{c}-.08^{* *} \\
(.02)\end{array}$ & $\begin{array}{l}-.07^{*} \\
(.03)\end{array}$ & .53 \\
\hline $\begin{array}{l}\text { Drop Sweden } \\
\text { as UMP source }\end{array}$ & $\begin{array}{c}-.08^{* *} \\
(.02) \\
\end{array}$ & $\begin{array}{l}-.08^{*} \\
(.03)\end{array}$ & .82 \\
\hline $\begin{array}{l}\text { Drop Switzerland } \\
\text { as UMP source }\end{array}$ & $\begin{array}{c}-.08^{* *} \\
(.02)\end{array}$ & $\begin{array}{c}-.11^{* *} \\
(.03)\end{array}$ & .41 \\
\hline $\begin{array}{l}\text { Drop Germany } \\
\text { as UMP source }\end{array}$ & $\begin{array}{c}-.08 * * \\
(.02) \\
\end{array}$ & $\begin{array}{l}-.08 * \\
(.03)\end{array}$ & .76 \\
\hline $\begin{array}{l}\text { Drop China, HK } \\
\text { as UMP source }\end{array}$ & $\begin{array}{c}-.08^{* *} \\
(.02) \\
\end{array}$ & $\begin{array}{l}-.08^{*} \\
(.03) \\
\end{array}$ & .83 \\
\hline $\begin{array}{l}\text { Drop Asians DCs } \\
\text { as UMP "target" }\end{array}$ & $\begin{array}{c}-.09 * * \\
(.03)\end{array}$ & $\begin{array}{l}-.11^{* *} \\
(.04)\end{array}$ & .65 \\
\hline $\begin{array}{l}\text { Drop Africans } \\
\text { as UMP "target" }\end{array}$ & $\begin{array}{c}-.09 * * \\
(.02) \\
\end{array}$ & $\begin{array}{l}-.07^{*} \\
(.03)\end{array}$ & .39 \\
\hline $\begin{array}{l}\text { Drop Latin/Caribbean } \\
\text { as UMP "target" }\end{array}$ & $\begin{array}{l}-.05^{*} \\
(.02) \\
\end{array}$ & $\begin{array}{l}-.07^{*} \\
(.03)\end{array}$ & .61 \\
\hline Drop $3 \sigma$ outliers & $\begin{array}{c}.07^{* *} \\
(.02)\end{array}$ & $\begin{array}{l}-.06^{*} \\
(.03)\end{array}$ & .68 \\
\hline
\end{tabular}

Coefficients, with robust standard errors (clustered by country-pair dyad) recorded in parentheses. Coefficients significantly different from zero at the .05 (.01) level marked by one (two) asterisk(s). Each cell stems from a separate regression. Least squares estimation; regressand is log bilateral imports in US\$. Binary regressors included but not recorded for exporter + importer in: a) currency union; and b) regional trade agreement. Fixed effects included for all sets of: a) exporter*quarter, b) importer*quarter, and c) exporter*importer. Quarterly data 2000Q1-2016Q2 for over 200 countries and territories; default regression has 1,325,058 observations. 


\section{Appendix Table A4: The Effect of Unconventional Monetary Policy on Exchange Rates}

\begin{tabular}{|c|c|c|c|c|c|c|c|}
\hline & 1 & 2 & 3 & 4 & 5 & 6 & 7 \\
\hline $\begin{array}{l}\text { Quantitative Easing } \\
\text { by Country } 1, \text { not Country } 2(1.8 \%)\end{array}$ & & $\begin{array}{c}-.58 * * \\
(.05)\end{array}$ & & & $\begin{array}{c}-.47^{* *} \\
(.06)\end{array}$ & $\begin{array}{c}-.47 * * \\
(.06)\end{array}$ & \\
\hline $\begin{array}{l}\text { Negative Nominal Interest rate } \\
\text { in Country } 1, \text { not Country } 2(2.0 \%)\end{array}$ & & & $\begin{array}{c}-.58 * * \\
(.06) \\
\end{array}$ & & $\begin{array}{c}-.35 * * \\
(.07) \\
\end{array}$ & $\begin{array}{c}-.35 * * \\
(.07) \\
\end{array}$ & \\
\hline $\begin{array}{l}\text { State-Contingent Forward Guidance } \\
\text { by Country 1, not Country } 2(0.3 \%)\end{array}$ & & & & $\begin{array}{c}-.15^{* *} \\
(.03) \\
\end{array}$ & $\begin{array}{l}-.05 \\
(.05)\end{array}$ & & \\
\hline $\begin{array}{l}\text { Either Quantitative Easing or Negative Nominal } \\
\text { Interest rate by Country 1, not Country } 2(2.7 \%)\end{array}$ & & & & & & & $\begin{array}{c}-.59 * * \\
(.05) \\
\end{array}$ \\
\hline Country 1-Country 2 Fixed Effects $(26,658)$ & Yes & Yes & Yes & Yes & Yes & Yes & Yes \\
\hline $\mathbf{R}^{\mathbf{2}}$ & .96 & .96 & .96 & .96 & .96 & .96 & .96 \\
\hline RMSE & .83 & .83 & .83 & .83 & .83 & .83 & .83 \\
\hline
\end{tabular}

Coefficients, with robust standard errors (clustered by: a) country $1^{*}$ quarter, b) country $2^{*}$ quarter, c) country-pair dyads) recorded in parentheses. Coefficients significantly different from zero at the .05 (.01) level marked by one (two) asterisk(s). Each column stems from a separate regression. Least squares estimation; regressand is log bilateral exchange rate, price in country 1 currency of a unit of country 2 currency. Binary regressor included but not recorded for both countries in regional trade agreement. Fixed effects included for all sets of country 1*country 2 dyads. Quarterly data 2000Q1-2016Q2 for over 200 countries and territories; $1,738,043$ observations. 


\section{Endnotes}

${ }^{1}$ Alternatively, Bernanke writes (2015, p9): “'Currency wars' is a colorful synonym for the familiar concept of competitive depreciation of exchange rates, with the goal of diverting world demand toward one's own exports ..."

2 This seems consistent with the historical record; the competitive devaluations of the 1930s are usually associated with exits from the gold-exchange standards (sometimes accompanied by capital controls), certainly unconventional monetary policy for its day.

${ }^{3}$ Nevertheless, I pursue the former briefly below, and also examine imports.

${ }^{4}$ This is consistent with Eaton et al. (2016), who do not discuss monetary policy in their discussion of the 2008-09 collapse of international trade.

${ }^{5}$ The $\left\{\lambda_{i t}\right\}$ fixed effects are country-specific and time-varying; for instance, there is one for all bilateral American exports for 2000Q1, another for all American exports in 2000Q2, and so forth. So, anything that is specific to an exporter (e.g., America) in a quarter (e.g., 2000Q1) is implicitly in the fixed effects; this includes GDP, GDP per capita, political shocks, and so forth. Similarly, $\left\{\psi_{\mathrm{jt}}\right\}$ picks up the importer effects.

${ }^{6}$ This too is consistent with Eaton et al. (2016) who argue that while aggregate demand and productivity shocks caused much of the declines in output associated with the Great Recession, the sources of the trade decline lay elsewhere, primarily in shocks to the investment efficiency of durables.

7 The (205) countries and territories are listed in Appendix Table A1.

${ }^{8}$ Colonial relationships cannot be recovered from the within estimator of (1) since there is no variation over time; accordingly, they are omitted from the equation.

9 This is mostly relevant for Japan, which engaged in QE from March 2001 through March 2006, but reversed these purchases by July 2006. More details are available in "Managing the Exit" by Yamaoka and Syed, IMF WP/10/114.

${ }_{10}$ Differences in timing between the announcement and implementation of QE are typically small, especially given the use of quarterly data; more details are available online.

11 Switzerland experienced negative nominal market rates from 2011 through 2014, but only officially lowered its policy rate below zero in 2015. Officially, but in a mostly technical sense, Sweden had negative rates in 2009-10, Norway from the Fall of 2015, and Hungary in 2016.

12 Future research on this topic could consider using continuous measures of UMP in place of discrete measures by, for instance, scaling QE by e.g., money, output, or global GDP, perhaps taking country size into importance.

${ }^{13}$ I create an average value of the nominal value of bilateral imports between two countries by averaging i's CIF imports from $\mathrm{j}$ and j's FOB exports to i, using U.S. dollar values from IMF's DoTS.

${ }^{14}$ This effect is the same order of magnitude as the export decline tabulated in Table 2, but slightly smaller; any effect on bilateral trade imbalances is likely to be negative but small (if, for some reason, one is interested in a bilateral trade imbalance).

15 During the sample, unconventional monetary policy has only been used by advanced countries, which is why I only drop sets of observations from developing countries.

${ }^{16}$ I use period-average nominal data, extracted from the IMF's International Financial Statistics. Also, for obvious reasons, I do not include the currency union binary variable as a control. 